Comparative Philosophy Volume 13, No. 1 (2022): 77-100

Open Access / ISSN 2151-6014 / www.comparativephilosophy.org

https://doi.org/10.31979/2151-6014(2022).130107

\title{
AESTHETICIZED TRAGEDY (KARUNARASA) AS AN INTELLECTUAL VIRTUE
}

\author{
LISA WIDDISON
}

\begin{abstract}
In contemporary virtue epistemology, responsibilist intellectual virtues in the tradition of Aristotle's moral theory are acquired character traits involving a motivational component and a success component. The motivational component is an emotion that regulates inquiry but which would ordinarily, and problematically, carry bias. In order to monitor the patterns of fallibility in emotions, reflection can correct beyond perceptual errors or logical fallacies. Emotions which survive reflection are less partial and hold more epistemic valance than egotistical emotions. Since the framework of virtue epistemology might be at a loss for monitoring emotions reflectively, given the fact emotions operate rapidly and tend to bypass cognitive functions, a theory of non-cognitive, egoless emotions, such as the Sanskrit aesthetic theory of rasa is a useful paradigm for epistemic value. Aestheticized emotions (rasa-s) have a place in emotion-evaluation. In particular, Abhinavagupta's realistic analysis of the aestheticized emotion of pathos (karunarasa) in the Abhinavabhāratī, shows that, "aestheticized tragedy," unlike ordinary compassion or pity, is an immersive but moving higher-order affective response that involves evaluating the transitions from one unreflective emotion to the next. The cognitive fallout for related virtues, such as compassion, is that karuna affords insight into the process of transformation. Subsequently, it is possible to articulate a new kind of intellectual virtue, one that regulates observation, anticipates attunement with sentient beings, and adds insight to the evaluative structure of pathos.
\end{abstract}

Keywords: emotion, intellectual virtue, karuna, rasa, Sanskrit aesthetics, taste and the sublime, virtue epistemology

[तमसा] अहो संविधानकम ।
एको रसः करुण एव निमित्तभेदाद्भिन्नः पृथक्पृथगिवाश्रयते विवर्तान् ।
आवर्तबुद्वुदतरड्गमयान्विकारानम्भो यथा सलिलमेव तु तत्समग्रम् । ।
भवभूति, उत्तररामचरित ३-४७

WIDDISON, LISA: Lecturer of Philosophy, University of Hawai ‘i-West O‘ahu, USA. Email: lisa888@hawaii.edu 
[Tamasā speaking] How confusing!

Only one rasa, karuna, on account of different causes one after the next persists like it rests in change. But on the whole it is only a flow, just as water in a whirlpool assumes the form of waves and bubbles. ${ }^{1}$

Bhavabhūti, Uttararāmacarita 3.47

\section{THE RASA THEORY OF AESTHETIC APPRECIATION}

An "intellectual virtue" is a human good of flourishing and happiness that can be theorized in different ways, though the idea perennially includes character traits of wisdom or a capacity for understanding. When some contemporary virtue theorists inspired by Aristotle's conception looked closely at the ways virtuous capacities might guide inquiry to reach understanding, they found that affective judgments about a cause for pleasure or pain, i.e., emotions, are present as motivational factors (as noted in the Nicomachean Ethics). Sometimes voluntary and sometimes involuntary, emotions can be cultivated. "Emotion" cultivated as a judgment of value in exercising virtue can be articulated either morally or intellectually. (Zagzebski, 1996) Intellectual virtues are critical in certain kinds of virtuous understanding that requires an agent, like knowledge of other people. (Dalmiya, 2001) The epistemically virtuous agent is someone who can be credited for avoiding error and reaching truth by an ability to inquire willingly and responsibly. For theorizing motivational emotions in virtue epistemology, the new insight from classical Sanskrit poetics is that some of an agent's epistemological emotions are also aesthetic.

Critical emphasis on the distinctly aesthetic quality of very different kinds of emotion (e.g., the erotic, comic, horrific, tragic etc.) has created a discourse around aestheticized emotions, the core of which is nowadays widely known from Sanskrit as rasa theory, or simply rasa. The saying, "happiness is like water" jalam iva sukham in Sanskrit expresses the fluid nature of positive emotions that is ordinarily difficult to maintain. It also expresses another direction of rapture, a more extraordinarily impossible to contain response to reach out to others in aesthetic appreciation. Rasa bubbles over from narratives of turmoil and tranquility. Bharata's list of eight distinct but interwoven rasa-s, all of which have general ordinary counterparts on a paradigmatic palette of dispositional emotions (sthāyibhāva), can be taken as kinds of aesthetic judgments because as Kant claimed, the imaginative faculty--a condition of the experiencing subject--refers only to a quality of beauty, or alternately of one's own sublimity. ${ }^{2}$

\footnotetext{
${ }^{1}$ Act 3.47. Kale $(2003,41)$ translates the same verse as follows: "The one sentiment of pathos [karunarasa] divided by a diversity of causes, undergoes different variations, as water assumes the different conditions of eddies, bubbles and waves, and it is all, never the less, but water."

${ }^{2}$ In the Critique of Judgment (CJ) Kant claims the pleasure of taste is a subjective condition of the judger herself: "an ability to judge an object in reference to the free lawfulness of the imagination" $(1790,240)$. A judgment of taste (by the ability to judge an object, or a way of presenting it, by means of a liking or
} 
In rasa, the subjective conditions for being carried away, rapture, or more descriptively, for having real embodied emotions that are reflective, is a contemplative possibility by enacting dispositional traces ( $v \bar{a} s a n \bar{a})$. The occurrence of rasa, depends on latent dispositions which are called the sthāyibhāva-s: rati (love/rapture), hāsa (mirth/laughter), śoka (sorrow), krodha (anger), utsāha (enthusiasum), bhaya (fear), jugupsā (revulsion), vismaya (astonishment), and śama or nirveda (a special form of tranquility or equanimity). Rasa-s include: śrngāra (the erotic/romantic), hāsya (comedy), karuna (tragedy/pathos), raudra (ferociousness), vìra (heroism), bhayānaka (horror), bībhatsa (disgust), adbhuta (wonder), and controversially, śānta (tranquility or quietude). ${ }^{3}$ Rasa-s have a general relation to ordinary emotions, but differ in that rasa is not evoked to account for merely personal, or mundane experiences. ${ }^{4}$ Aestheticization (the process of generalization to affectively reach a quality of beauty or sublimity) transforms the potentially painful emotions that artists find ways suggest into contemplative happiness. Karuna, the emotion with tragedy as an aestheticized artobject, is grounded in a capacity to feel painful emotions, and yet karuna is not a painful experience. Rather, the bittersweet taste of tragedy becomes refined in karuna. Aestheticization reflectively liquifies forms of suffering imagined through the emotion palate of a connoisseur. On its path of inquiry, understanding may be shared in the stories we tell.

'Rasa' as 'aesthetic-emotion' was formally introduced in the Nātyaśāstra (NS), a canonical and comprehensive text on dramaturgy (c.200 BCE - $200 \mathrm{CE}$ ) by Bharatamuni (the sage Bharata). Subsequently, rasa theory has been applied to a variety of arts, including poetry, narrative, dance, music, sculpture, painting and of course, theater. Ordinarily, rasa can mean a sap, taste, flavor, liquid, juice, medicinal tonic, joy or rapture. Relating the rasa of theater to an elixir, Bharata put a descriptive vocabulary into place with the analogy of cooking, in which raw ingredients are

disliking devoid of all interest) makes use of the productive power of the imagination, apart from the aspect responsible for bringing about the recognition of a concept, the reproductive imagination. The object of such a liking, according to Kant is called by the quality beautiful. $(1790,211)$.

${ }^{3}$ Bharata explicitly mentions only eight, the ninth emotion of tranquility is defended in Abhinavagupta's commentary on the NS, the Abhinavabhratī VI. There we see śäntarasa emerge following his critique of views regarding rasa production. His commentary on the NS is itself a canonical text, as a synthesis of opposing views, with insights into the polemics of lost commentaries, such as Bhattanāyaka's Sahriayadarpaṇa.

${ }^{4}$ All cultures account for some basic feelings, such as "fear" or "love," the particulars of which need not be universally shared. Yet in a sense the rasa experience is taken as a break from even those particulars of ordinary or worldly relations. An array of ordinary emotion-states (bhāva) is part of the background of any audience, not merely because of cultural conditions nor because of a neuro-biological basis of affective response for sorting emotion-types, like the emotion scheme Paul Ekman proposed where basic emotions have a scientific basis in evolutionary biology. (Ekman 1999, 46). Jesse Prinz rejects a purely biological basis for emotions, not by fully arguing for a cultural basis, but instead to say that emotions are both conditioned, and culturally informed (Prinz, 2004). The ontology of rasa is also such that producing aesthetic enjoyment is both biologically and culturally informed, yet transcendental according to Abhinava. 
transformed in the kitchen to manifest something relishable. ${ }^{5}$ Though the "Rasa Suttra" of Bharata's NS VI.32 (tatra vibhāvānubhāva vyabhicāri samyogād rasaḥ niṣpattih), omits reference to stable emotion dispositions, the aphorism intimates that rasa is the essence of an agent, one who affectively judges the cause-effect conditions of emotions.

Instead of pointing out stable emotion dispositions that usually motivate a person, the "Rasa Sūtra" indicates that the conjunction (samyoga) of necessary conditions: determinants (aesthetic objects, vibhāva-s), consequents (possible experiences, $a n u b h \bar{a} v a-s$ ), and fleeting emotion states (viabhicāribhāva-s) is sufficient for audience rapport. The result is a "refined" or "cooked" emotion-essence that a spectator feels in art-experiences. This is aesthetic pleasure (rasāsvāda) as a sentimentally construed tasting experience. For example, a desolate Ophelia by the riverbank, ornate dress and symbolic flowers are examples of aesthetic objects. A possible experience, or effect is her being driven to suicide. Although "karuna," is occasionally mis-transliterated or translated as the moral virtue, i.e., karuṇa/compassion, the aesthetic idea "karuna" is a relishable sap of sadness, or tragedy, and not a moral virtue. ${ }^{6}$ If the aesthetic emotion of karuna leads to moral virtue then it may well be because aestheticizing tragedy, which need not be a moral act, is an intellectual act, one that moves an agent emotionally. The rasa formula captures 'a spectator' as one whose body engages empatheticaly.

When looking at a performance or painting of Ophelia, the gestures on Ophelia's face and hands, which seem involuntary, elicit an embodied response in terms of spectator-emotion. ${ }^{7}$ The audience, who is attuned to, and reflectively aware of a tragedy unfolding, should feel a certain shock of understanding when they see Ophelia. Yet it would be a mistake to assume that there is a mimetic symmetry between art and life. Theoretically distinguishable from "personal" emotions, rasa-s are real 'transpersonal' emotional responses to experiences that are pictured through spectators' imaginative engagement with art, even about the un-experienceable. According to Abhinavagupta, it is a fact about rasa that a spectator can be further immersed in a particular

\footnotetext{
5 vyañjanaușadhisamyogo yathānnam svādutām nayet/ evam bhāvā rasāścaiva bhāvayanti parasparam// NS 6.37

${ }^{6}$ On the matter of translating karuna as "tragedy" see Indian Poetics and Western thought (Kushwaha 1988, 130). There, A.C. Sukla renders karunarasa to be 'tragic Joy.' If not a stronger view of karuna as a moral then atleast a comparative basis between the philosophies of Aristotle and Abhinavagupta is supported by Geoff Ashton and Sonja Tanner in Philosophy East \& West (2016, 13-39).
}

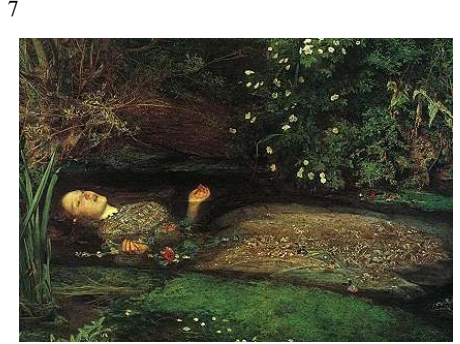

Artist: Sir John Everett Millais, Bt 1829-1896 Ophelia Oil on Canvas 1851-2 Tate, London Presented by Sir Henry Tate1894 Reference N01506 
configuration of emotions which has lessons for every aspect of life, wealth or power (artha), pleasure (kāma), duty or responsibility (dharma) and liberation (mokșa), while transcending the trappings of merely personal emotions to which these human aims may refer (e.g., greed, lust, and bias). ${ }^{8}$ He stresses the possibility for spiritual progress in the rasa experience, but in any case, there is a secular intellectual value in rasa for enjoyment.

Recently, Vittorio Gallesi has claimed that embodied simulation is relevant to aesthetics both through mirror mechanisms, and through symbol making gestures. "Beholders' eyes catch not only information about the shape, direction, and texture of the cuts or strokes, but by means of embodied simulation they breach into the actual motor expression of the artist when creating the artwork. The sensory-motor component of image perception together with the jointly evoked emotional reaction allow beholders to feel the artwork in an embodied manner." $(2017,193)$ Gallesi argues that the mirroring mechanisms generate an "intentional attunement" that is suitable for embodied simulation. Recognition of other selves, intersubjective communication and implicit understanding is supposed to be possible on this track of empathy. (2017, 188189) Research compiled by Despina Stamatopoulou shows: "As such, aesthetic experiences can become a field of 'becoming instead of being', when the motivational urge to act upon (feeling for the other) gets back to the beholder to be 'played within', as potentialities of vicarious I-feelings, while the beholder retains the 'intersubjective ties' with the art object (engagement)." $(2017,184)^{9}$ Aesthetic experience stands at the "edge of action" but it still motivates. Thus, Samatopoulou believes that a receptive self stays at the background, feeding into a hypothetical imagination while becoming attuned to art-objects. Likewise, Aristotle considered aesthetic emotion to follow on cognizance of a possibility, or "as if" mode, which makes use of the imagination, but does not determine anything about the way things necessarily are, have been, or will be. The powers of cognizing objects of art, and ruminating on the meaning is just contemplative. The process of generalization in Sanskrit (sādhāran̄ikārana) ${ }^{10}$ is emphasized by Abhinavagupta as transcendental, but Aristotle also maintains that aesthetic experience is a different way of seeing, or being in the world.

Rae Langton also discusses the roles the empathetic observer can navigate, sometimes based on the thought: "I could have been someone else" which is imaginable, if not impossible. "The illusion, if it is an illusion, is not obvious. And we can wonder, also, if there would be a price to pay for its banishment." $(2018,100-101)$ Failures of the imagination are an incalculable loss to the agent that cannot be gauged in terms of assessing numbers of beliefs that are factual. ${ }^{11}$ The Aristotelian notion of

\footnotetext{
${ }^{8}$ Agreeing with Bhāmaha, Abhinavagupta says in commentary (on Ānandavardhana's Dhvanyāloka) about suggesting emotion in Locana, "knowledge and pleasure for the reader are both present" that incidentally confers skill in the knower of each of the above aims. Masson and Patwardhan $(1969,54)$

${ }^{9}$ Stamatopoulou (2017) is not specifically considering rasa, the above insights are generally descriptive account, and serve to support a unity to aesthetic exprerience across differing conditions.

10 'Sädhäran̄ībhāvah' is a technical term for Abhinavagupta, in Abhinavabhāratī., 1.107

${ }^{11}$ Arindam Chakrabarti suggests that given our natural process of mind-reading, we seem to read others' feelings, quite easily, reliably though fallibly through: facial/muscular mimicry and emotional contagion,
} 
'possibility' in the Poetics, is critical for a spectator who changes as a knower, makes reappraisals and based on reflection, and questions courses of action. But more in tune with the rasa theorist, Samatopoulou emphasizes that the self is de-centered. The deeper metaphysical commitment of Abhinavagupta holds that it is unproblematic to allow that there can be a dissolution of the distinction between "I" and "You" without a loss of Self. Decentering the Self chimes with the fact that rasa-s "life-lessons" are free of cost, or at no personal loss.

As with most accounts of aesthetic enjoyment, the rasa experience is thought to be inherently pleasurable even when negative emotions of fear and pity are conjured up. Real-life horror motivates a different kind of response than the reflective horror an audience feels, and even enjoys. An audience can relish the horrific sight of Medea or Othello's jealous rage, but to actually take pleasure in watching a crime of passion would be a perverse, irrational response. The reason by which no one rushes to the stage to stop Othello from choking Desdemona in a compelling performance, is an aesthetically normative moment to continue judging with feeling.

Rasa theory explains the appearance-reality distinction as only part of an audience's imaginative engagement with a dramatic performance. A discriminating audience can distinguish between appearance and reality, but also the reality of one's own desires from the aesthetic emotion. Abhinavagupta claims that closely identifying with characters in a play through personalized emotions constitutes one of seven major obstacles to aesthetic enjoyment, hindering an audience's rasa experience. ${ }^{12}$ The seven opposing-states that interfere with the process of rasa appreciation are: (1) Thinking that a narrative (e.g., that the rage of Medea) is factually impossible or unimaginable; (2) Thinking of a narrative only historically; (3) Taking the rapture as a private emotion; (4) Insensitivity; (5) Unclarity; (6) Seeming irrelevant to purposes of life; and (7) Doubt that an aesthetic construction (artwork) works as engaging. ${ }^{13}$ Abhinavagupta builds on this theoretical framework in categorizing emotions to support the position that the rasa-bhāva distinction is a result of a perspectival shift away from spatiallytemporarily thinking about persons, places, etc. It can be an awakening to the timeless beauty, or the spiritual underpinnings of art. Like meaning which is not lost when it is shared, enjoyment will overflow because rasa appreciation is disinterested personally, but the agent remaind interested. Pace Bijoy Boruah (2016), trans-personal emotions can constitute judgments in art-experiences, just as ordinary emotions are said to constitute evaluative judgments about one's own (mostly selfish) vulnerabilities in

eye-direction detection, shared attention mechanism, face-reading cues, theory-deployment, and simulation (imaginative role-reversal). Cautiously, we could "propose a newly recognized but perennially used knowledge-source or pramanna: EMPATHY, which is a mixture of all six of these. That solves the epistemological problem [of knowing others]." $(2015,108)$ However, the aesthetic turn to reflective emotions seems to be critical even for embodied knowledge.

${ }^{12}$ Pace Abhinavagupta in the Abhinavabhrati VI, it is by circumventing the objective impediments of the ego obstacles (vighna) to personal distancing and aesthetic immersion are removed.

${ }^{13}$ Arindam Chakrabarti summarizes these points $(2009,197$, and 2016, 11-12) from Abhinavabhāratī, 6.32. narrated beginning on page 274 Baroda ed. 
ordinary experiences (Nussbaum, 2018). Instead of being merely personal, rasa-s can be read as reflective, and open-ended judgments of taste.

Bharata and Abhinavagupta, elucidate the respective distinction between aesthetic emotion (rasa) and ordinary emotion ( $b h \bar{a} v a$ ) systematically in two chapters of the NS (VI, the "Rasādhāya" and VII, the "Bhāvādhāya"). Though scholars tend to focus the former, in the overlooked seventh chapter a theory of emotion contagion, with fortynine common states, accounts for the connection between the two kinds of experiences. Freely attending (in the Kantian sense of imaginative free play) to the causal relations between one emotion and the next puts the experiencer who is imagining causes, effects and pop-up emotions of surprise and shock, in a state of rest in pure subjectivity without an objectified goal. As S.C. Sen Gupta points out in "Hamlet in the Light of Indian Poetics" (Kushwaha ed., 1988, 260-1), the hero's torturing of Ophelia is a form of selflaceration. ${ }^{14}$ Clearly, his self-harm results as from any harm to a self-related other. Abhinavagupta famously concurs with the lack of basis for directly seeing a self as not also "I". Imaginatively, the experience is complete like a moment of a yogin's understanding, and no lack in awareness, even to have the lack of pain, is is desired. For a spectator qua inquiring rasika, communal enjoyment motivates extra attention due to relations of suffering, as much if not more than the soteriological aims of art; rasa-s are a transcendent avenue to yogic bliss, similar to the experience of supreme Brahman. Any rasa is to be experienced by anyone, including radically different kinds of folks.

\section{ORDINARY COMPASSION AND INTELLECTUAL VIRTUE (IVS)}

Feeling with others and for others is a one of the ways we navigate the world. Since knowledge of reality depends on an intersubjective grasp of the world beyond one's own perspective, knowledge of others in an epistemic community is critical. Ordinarily, emotions express vulnerabilities and convey pleasure or displeasure to others. Thus, the first substantial link between compassion and inquiry is the motivated disposition to know the reality of others. Unlike selfish pity, some knowledge, especially that of other minds, is dependent on openness and alignment. Not being about art-experience, ordinary compassion takes the form of empathy in instances of knowing the needs of others. According to Amy Coplan, "Only empathy that combines affective matching, other-oriented perspective-taking, and self-other differentiation provides experiential understanding." $(2011,17)$ That is, one's own feeling provides knowledge of how others feel and will act. On the track of empathy, we might know others as intentional directly from perceiving their feelings. According to Zahavi and Gallagher:

Empathy is defined as a form of intentionality in which one is directed towards the other's lived experiences. Any intentional act that discloses or presents the other's subjectivity from the second-person perspective counts as empathy. Although empathy, so understood, is based on perception (of the other's bodily presence) and can involve inference in difficult

${ }^{14}$ This is a key comparative Sanskrit-Shakspearean study beyond pathos that considers the ontological analysis of pain and the rasa technical process of generalization through pain-bearing characters. 
or problematic situations (where one has to work out how another person feels about something), it is not reducible to some additive combination of perception and inference. $(2008,183)$

We can add that as a virtue compassion thickens empathy. Compassion is when empathizing successfully aligns with the feelings of others to create a balanced understanding of how to help, and is transformed into actions of assistance. Though Aristotle did not speak of compassion as an intellectual virtue, he did theorize the relatively non-virtuous emotion of 'pity'entailing cognizance of the undeserved suffering of another (Rhetoric, Book 2, Ch. VIII, Poetics). Pity is a self-other regarding emotion of dread, recurring as the generalized feeling of pathos through a productive act of mimesis in the context of aesthetics. But contemporary virtue epistemologists rightfully welcome ordinary compassion as an IV in Aristotelian terms. Roberts and Woods describe the framework of compassion as the evaluative perception of another's vulnerabilities, such as noticing when harm might be done:

Aristotle allows at least two different kinds of "cognition" as exemplifying practical wisdom. It is a power of deliberation (bouleusis; see Nicomachean Ethics 1139a12-15), but also a power of perception (aisthésis; see 1142a25-30). Deliberation is an activity, but perception involves an element of passivity. This mixture of activity and passivity is typical of virtue exemplifications. For example, the compassionate person deliberates how best to help somebody in trouble, and then acts intentionally on the result of his deliberation; but also, spontaneously and involuntarily, he notices people's troubles where less compassionate people do not notice, and spontaneously and involuntarily wants to help. $(306,317)^{15}$

Compassion as an intellectual virtue of relating suffering to vulnerabilities connects the two kinds of cognition, deliberation (as a kind of reflection) and perception (which based in feeling). Thus, ordinary compassion is direct perception of particular bodies and deliberation about their needs that is motivated by a passivity, or suffering. It is not a joy, nor a generalized tragedy.

As Emmanuel Housset comments, unlike pity that is about a distant other, compassion as we know it in ordinary life is a feeling for a particular, and separate, other. "Consequently, compassion is never that disinterested love of humanity in general...its aim is not to love an impersonal essence or what man could become beyond his weaknesses, but to love the concrete individual person as he gives himself, with his unique history and flesh." $(2011,81)$ Furthermore, compassion cannot be unselfish if it is motivated by pain in seeing the suffering of another. The com of passion is a feeling passion, or passivity with others, not that pain of others. And if unhappiness with another unhappiness is the basis of a virtue, then the pain motivating assistance is not homogenous, but multiplied out of proportion, and biased. Taking a

\footnotetext{
${ }^{15}$ Robert C. Roberts \& W. Jay Wood discuss the IV of compassion through the lens of an observant Professor participating in Stanley Milgram's experiments who resisted punishing students to the point of administering shocks.
} 
cue from Aristotle's virtue theory, Linda Zagzebski has claimed that a "motive" in inquiry is "an emotion or feeling that initiates and directs action towards an end." $(1996,131)^{16}$ Since every inquiry needs to be initiated, there is a mismatch between impartial inquiry into the nature of suffering and unselfishness. However, karunarasa evades this criticism, and works as a transcendental condition for the possibility for real compassion, without itself being compassion.

The Buddhist virtue of having compassion, karuna $\bar{a}$ can further problematize what we take to be ordinary compassion, but it need not. Though the Four Noble Truths correctly state that life involves suffering (śoka), transforming a tragic circumstance into wisdom takes understanding. Śoka is the experience of suffering, conceptualized as a background emotion-disposition in rasa theory. Śāntideva claims: "There is no doubt that those whose selfhood is compassion have taken this entire world for themselves..." (Skilton, 1995, 61-2) ${ }^{17}$ For an aesthete also, karuna could be an avenue to the aim of great compassion (karunāa) if judgments then encompass all beings as if containing the whole world universally. While the whole world may in fact be aestheticized in a narrative, and encompassed in an act of tragic joy, the Buddhist response resists the transcendent otherworldly explanation that Abhinavagupta posits in literature (e.g., by taking the Buddhist themed play by Harșa, the Nāgānanda as an example where karunarasa leads to śäntarasa). In the Pratyabhijñā philosophy of Abhinagupta, even actual compassion (dayā) flows from the completeness of the self, not the emptiness of the self. (Ratié, 2009) The nature of the self is an expression of divine joy (anandamayi). In moments of sadness there is an inherent savoring to be realized, not of the ego, but of a willingly recollected forgotten unity with others. This taste of tragedy (karunarasa) may be compassion aestheticized but only in the sense that the passion in compassion is taken literally to mean a communal disposition (from Latin pati 'suffer') that is transformed. Karunarasa is an affective insight of each and every other's brokenness from the whole (in for instance, Ophelia's individual brokenness from all).

\section{AESTHETIC EXPERIENCE AND INTELLECTUAL VIRTUE}

In the sense that there is an ethics of how to know ourselves, theorizing knowledge has a normative dimension. Aristotle discusses two kinds of virtue in the Nicomachean Ethics Book II: virtues of thought and virtues of character. ${ }^{18} \mathrm{On}$ occasion,

\footnotetext{
${ }^{16}$ This is also the point from which St. Thomas begins his reflection on the emotion of love as a reaching forth, stretching toward some kind of object or "kind of motion toward a thing".

${ }^{17}$ In "Perfection of Forbearance" verse 126) Wisdom and compassion are invariably linked, in Buddhist thought, because of the ontological identification of samsāra with nirvāna. For a consideration of the theory of compassion without reference to aesthetic emotion see Sāntideva's Bodhicaryāvatāram.

${ }^{18}$ In particular Book XI also pertains to intellectual virtues. Any virtue requires a corresponding emotion disposition to be creatively balanced between extremes. The emotion-states of the intellectual virtues might be ultra-rational in this regard. If virtuous emotions turn out to be inherently pleasurable, as Book $\mathrm{X}$ suggests, a unified theory of intellectual virtue and emotions is still incomplete with what we have from Aristotle. The processing of painful emotions to be integrated with agency depends on an intellectual pleasure taken in the act of judging well.
} 
contemporary virtue epistemology hybridizes the two notions. According to Aristotle, virtue is a willed state, which posits emotion-dispositions (courage, forbearance, etc.) at the heart of practical virtues (bravery, endurance, etc.), and consists in a mean relative to an individual, defined by reference to reason, just as prudent person would define it. (1107a). The Aristotelian inspired theory in virtue responsibilism (Zagzebski, 1996) requires that an agent embody dispositions for the sake of understanding, and cultivate character traits that lead to inquiry. Reflective character traits, such as "consistency" and "carefulness" regulate the ability to inquire well and reach understanding.

Now Aristotle's recipe for happiness in the Nicomachean Ethics should have an uneasy aftertaste for those who also love his aesthetics. He claims that happiness (the product of virtue) is not found in play diversions. Rather, we need to divert ourselves so that we can work, and we work to be happy (1176b29-36). "Happiness" is an activity expressing virtue in a complete life. The activity of study expresses a human being's unique virtue and makes complete happiness. 'Study,' broadly taken, must aim at a desired end if not "the supreme objects of knowledge" (1177a20-21). Whatever the objects of knowledge are, the supreme epistemic virtue is the natural ruler of faculties - the capacity for understanding heavily shaped by education. Though, as if diversions are also an avenue to a higher end, in Book II, Aristotle gives some advice to the man who is not fortunate enough to receive a proper education: Turn to the poets! ${ }^{19}$ Why? The simple answer is that human beings need an emotional education in order to study, learn, and contemplate virtues of inquiry for its own sake. Poetry shakes up emotions and gets the desire to learn directed at some end, even if only a temporary one. Then, we puzzle, we practice, and learn how to learn. Though there is also a deeper picture. Character traits are cognitively significant for epistemology because they decide the direction of inquiry and right objects of knowledge. ${ }^{20}$

Intellectual virtue is a trait manifested by learning to take pleasure in a willed state that decides on the right objects of knowledge or grasping reality as it is. In terms of feeling, one is oriented to grasp relations non-propositionally. Not that a virtue is not a mere feeling, because feelings do not determine goodness or truth. For Aristotle, being a good judge requires a broad education (1095a). At the same time, education should be specialized, like medical treatment (1180b7-9). This is a connection that may call to mind the medicinal use of rasa-s in Āyurveda.

Across divergent traditions, a theory of humors runs parallel to a mind-body alteration in aesthetic appreciation. Channeling emotions has a relation to aesthetic appreciation and emotional balance. Abhinavagupta claims that it is because karuna is sorrow (i.e., śoka) transformed into a self-fulfilling essence of pathos that we return to the theater to experience the sap of tragedy. The meaning of refined sorrow is not

\footnotetext{
${ }^{19}$ Quoting Hesiod, Works and Days, Aristotle slyly suggests that the person who lacks a starting point for understanding virtue (talent or education) and cannot recognize an authority therein, to 'seek it out' this way. (1095b)

${ }^{20}$ The responsibilist position in contemporary virtue epistemology especially removes emphasis from true beliefs as the only source of epistemic value. Hookway $(2003,187)$ is another analytic source for more on character trait/agent centered epistemologies.
} 
merely that suffering is constitutive of sentient beings, but rather that in order to be sentient there is first a general condition of enjoyment (camatkāra) in being conscious. For the rasika, a way of purifying emotions is through the process of refining consciousness in aesthetic generalization (sādhāran̄ikāraṇa). This implies that every experience of suffering is a private lack, and there is no common essence of suffering the way there is for a rasa. Pain is not general, it is particular. Conversely, karuna is the conscious awareness of a power to feel freely that flows between sentient beings. When an audience grasps Ophelia with imaginative rapport then she becomes part of a discourse on dispelling obstacles to union with a beloved or achieving freedom from misunderstanding.

\section{KARUNA: AESTHETICIZED PATHOS AS TRAGEDY}

Aristotle was right to see that something cognitive is given in encountering art-objects, because in a sense it is true that we must jump past a cognitive hurdle to get there but, aesthetic enjoyment need not terminate in cognition. As a middle-ground, aestheticemotions are not limited to the 'arousal' on the part of the spectator, but cognitive apprehension is no small part of it. When the spectator infers: "that could just as well be me in that circumstance," the experience is private or personal, and tragedy comes at the cost of some pleasure. We could insist the contrast between aesthetic immersion (tanmayībhāvah) and catharsis is that an audience can be immersed in sorrow minus the pain (śoka). Tragedy mingles with joy. Previous comparisons with Aristotle's concept of pathos and theory of catharsis with the rasa theory of Sanskrit aesthetics have in fact been made before. (Singal 1977) Points of convergence reveal the universality of conceptualizing suffering, grief, and pity in aesthetic appreciation because all sentient beings have the capacity for aesthetic enjoyment insofar as they are also rational beings, on both counts. We will add that from the virtue perspective, the judgment is willed and ongoing.

A classic example is of the spectator who is reduced to tears because of the fate of Oedipus. No matter how many times the connoisseur has seen the play, she will be transfixed by images showing the basic facts of the story. Unlike particular people, who are objects of ordinary pity, the particular actor that captures the audience's imagination in a presentation of misfortune is irrelevant. In fact, the better one knows just the plot, and the less one considers the actors personally, the more one will be moved by the quality of the performance and carried away in rapture. Since suffering is a cyclical phenomenon (as the Buddhists correctly emphasize), ordinary pity may be one of the most communally experienced emotion, but it is not pleasant-we avoid occasions of pity. In the theater, the cycle of this painful emotion is made uniformly pleasurable. Not that all aesthetic objects have karuna or pathos, but the process of aesthetic generalization is most spread out with karuna. Seeing the steps between suffering, and pity, reveals relations between emotions that might seem unconnected in absence of reflection. If we look carefully at how we proceed with a presentation of karuna from a particular to a universal, then we find that the agent's power of pathos in karuna depends on a decentering stance. 
As we saw, Bharata put a descriptive vocabulary into place with the analogy of cooking, in which raw ingredients (of emotion) are transformed in the kitchen (of the embodied mind) to manifest something relishable (aestheticized-emotion enjoyment). ${ }^{21}$ His "Rasa Sūtra" omits reference to stable personal emotions such as pity (śoka). The recipe for karuna-rasa calls for the conjunction of necessary [aesthetic] conditions: determinants (vibhāva-s) in the sentiment of the tragic, they are the imagined vulnerabilities of a character plus a hostile environment seen in context), consequents (anubhāva-s), enacted experiences of harm, and transient states (vyabhicāribhāva-s) presentations of pain that the spectator senses. Phenomenologically, expressions of suffering have an empathetic impact because, as cognitive scientists confirm, "Mirror neurons (and shared representations) are neutral — neither first-nor third-person- they are activated both for my own action and for observation of the other's action: activation of the system simulates the intentional action but not the agent." (Zahavi $2008,178)^{22}$ More is needed for a sufficient condition of rasa. A "conjunction" (samyoga) of the determinants, consequents, and transient states (collectively: vibhāvadi), is the reflective basis for spectator-mirroring of some embodied indicators of emotions (tears, trembling, etc.) with karuna. Famously, in a paradigm example where Vālmīki was inspired in pathos to compose a couplet, his anger arose on account of witnessing an insensitive act--a mating bird being killed in idle hunter.

This passage from the Rāmāyana of Vālmīki is often referred for the sake of exemplifying the process of rasa. Ānandavardhana and Abhinavagupta also make note of it to illustrate karuna. At the start of Ramāyana Book I, the author-sage Vālmîki spontaneously discovers the form of a couplet or śloka, through a surprising encounter when he is immersed in the charm of the forest. Thus, we see the stages of Vālmīki's personal transformation drawn out, generating a picture of the theoretical divisions within the construction of appreciation: artist, protagonist, and audience for the artexperience, by his being moved from pity, to inspired, and then amazed. After emerging from a bath in an exceptionally clear and lovely pool of the river, Tamasā, ${ }^{23} \mathrm{Va}$ lmîki witnesses a sorrowful scene: a poor bird's screech in agony as a hunter directs an arrow into her mate. 'Vālmīki' responds with pity, and aptly expresses it in a spontaneous verse, cursing the hunter. Describing himself, Vālmīki says: "Then, in the intensity of this feeling of compassion (karuna), the brahman thought, 'This is wrong.' Hearing the krauñca hen wailing, he uttered these words: 'Since Nishāda, you killed one of this pair of krauñcas, distracted at the height of passion, you shall not live for very long." 24

\footnotetext{
${ }^{21}$ vyañjanaușadhisamyogo yathā annam svādutām nayet/ evam bhāvā rasāścaiva bhāvayanti parasparam// NS 6.37

${ }^{22}$ As Zahavi and Gallagher point out: "that the same areas of my brain that are activated when I engage in intentional action are also activated when I see you perform the same or similar intentional action [for] 'shared representations' in several areas" $(2008,167)$.

${ }^{23}$ A name signifying murky or muddled darkness, see Bhavabhūti quote above where she also names karuna as the single rasa with mutating forms.

${ }^{24}$ Tatah karuna veditvād adharmo 'yam iti...dvijah niśämya rudatīn krauñcīm idam vacanam abravīt. Mā nișāda pratișthām tvam agamaḥ śāśvatīh samāh yat krauñca mithunād ekam avadhīh kāma mohitam! (Goldman trans., 2005, 46-47)
} 
This expression itself becomes an object of contemplation while Vālmīki hears himself uttering it.

Another verse immediately takes the first as its object: "And even as he stood watching and spoke in this way, this thought arose in his heart, 'Stricken with grief for this bird, what is this I have uttered?"' He captures the moment of transformation from a mere personal stance to the aesthetic bliss of a transpersonal stance. The image of a visionary (Vâlmīki), who is in the right place (a beautiful forest), at the right time (during a disruption), reacting (with shock, anger, sorrow) and the consequent experience of inspiration, results in the protagonist's (Vālmīki's) ordinary experience of śoka. Critically, Vālmīki makes no ordinary investigation into the matter of poetics, either. He does not ask how it was that he himself uttered an emotive verse. He clearly asks what it is. Far from unnamable, Vālmīki puns a neologism on a pathos-like word. Through extraordinary insight, ordinary pity (śoka), becomes śloka, or verse. Poetic insight sets into motion a new way of theorizing about emotion. The hunter proved tastelessness is an affront to any sensitive observer who witnesses the painful imagery. The move to curse a hunter in rhyme was a response to directly seeing a cause of suffering. As clue to our contemporary theorizing of compassion as an intellectual virtue, a śloka can put a break between what has happened, is happening, and will happen, for our own subjective power of consciousness to consider events extemporaneously. Narrative and art forms allow a spectator to step outside of a sequence of events, critically slow down the process for gaining distance, and from one image to the next, witness the vulnerable relations that experiences of hostility conceal.

If any emotion-ideas are universal in aesthetic theory then a variant of pathos as sorrow, or pity, is one such instance. In particular, we may be hard pressed to find a conception of tragedy which is not on every list of basic emotions, let alone aesthetic ones. ${ }^{25}$ Aristotle's notion of pathos also superficially resembles karunarasa. Arousing emotions in an audience is a necessary feature of Aristotelian tragedies, where a personal emotion, such as pity, is felt at undeserved misfortune, or fear for another like oneself. (Sorabji, 2000, 24) ${ }^{26}$ Aristotle argued, just as Abhinavagupta's predecessor, Śankuka, that the audience makes an inference based on imitations by actors. ${ }^{27}$ Regarding another who has an emotion as the object of pathos, spectators may respond with a range of shared emotions (Woodruff 2013, 59-63) ${ }^{28}$ But in Aristotle's theory, the eliminative function of catharsis only partially explains the stream of emotions. The

\footnotetext{
${ }^{25}$ Dividing aesthetic emotions into Comedy and Tragedy may be one way to give a culturally informed structure to reflective emotions. Yet, Woodruff (2013) differientates 'spectator emotions' in emotiontheory prior to contrasting 'ownerless emotions' with shared emotions in Greek Tragedy (2016).

${ }^{26}$ In Poetics VI, 1449b

${ }^{27}$ Richard Sorbji helps makes Aristotle's cognitive stance clear: "both fear and pity are aroused by showing that suffering has come to someone who is like us (homoious)." Aristotle, unlike the Stoic Seneca holds that pathos is genuine fear for oneself. As long as the fear is not excessive, it will support the pity tragedy is supposed to produce. (Sorabji, 2000, 24)

${ }^{28}$ Woodruff also claims that Greek theater theory of tragic-emotion is cognitive in the sense of making judgments: "Especially in the plays of Sophocles, the audience encounters characters who show compassion." In the case of an old disgusting Oedipus, those with homes only wish to dive him away, until Theseus recognizes the generality of ill-luck around being forced to wander $(2016,147)$.
} 
inward flow of karunarasa is a positive enjoyment of the essence of self, via the negative shedding of selfish emotions. If in catharsis, emotions are expunged, in the aesthetic rapture of rasa (camatkāra) they are they are savored.

With every rasa, a personal emotion-disposition of the spectator must be latent for there to be an experience of savoring. Śrngāra (the erotic), for instance, is experienceable only because rati (sexual love), as an emotion-disposition is latent. The same holds for the aesthetic emotion of ordinary anger (krodha), and the ferocious (raudra). In discussing karuna, in the Abhinavabhāratī, Abhinavagupta speaks of a similar emotion which is not so much savored, dayā. 'Day $\bar{a}$ ' also means compassion, and it is informed by a need for rescue, or pity. However, in seeing someone who has compassion, others do not necessarily follow suit, express and act with care. So too, the imitation of suffering cannot bring about the feeling of pity. Imitating any emotion makes a pseudo-rasa (rasābhāsa) only brings laughter. Said against the earlier theorist, Śankuka, who happens to posit a theory similar to the Aristotelian theory of mimesis, the cruel act of imitation is actually a comic presentation according to Abhinavagupta. But the point of the example is to show that aestheticized tragedy, pathos or karuna, is not an imitation, nor is daya the latent disposition (śoka) that karuna would imitate. Like the erotic sentiment (s'rngāra), the word 'sexy' merely denotes a meaning that is unable to make "sexiness" just by naming it.

Karuna does not arise from imitating or naming day $\bar{a}$, but rather from seeing connections between hurt, separation and tragedy constituting sorrow (śoka), and anticipating other sentiments such as anger, wrath, or fury (raudra). When Medea rages, spectators see connections beyond selfish reason, and sensativly may feel for someone they might otherwise condemn outside the imaginary realm of the theater. Abhinavagupta claims that it is well known that those who have karuna are sensitive. Aesthetic judgment strengthens the communicability of suggested agreements in meaning (samjña $)$. Kant's claim about taste also seems to be that universal communicability is a sufficient condition for aesthetic enjoyment. In the CJ Kant considers the fact that we do not really concern ourselves objects as such in artexperiences. All cognitive beings are capable of reflection because of the same capacity of cognition in general from one person to the next. Characters such as Medea are a possibility for harmonizing the cognitive powers of imagination and understanding.

Rasa must also overflow in discourse. With emotive objects of art, the features of the performance, etc., are such that constructions (vibhāviadi) are causally geared towards making an audience response with tears, or shaking, etc. ${ }^{29}$ Thus, although a rasa is not a personal emotion, the conjunction (samyoga) of the "Rasa Sūtra" occurs in the embodied imagination of the spectator. In the mind, a certain fittingness of a quality (guna, or beauty in Kant's theory) is a sufficient condition for rasa. ${ }^{30}$ On this point Bharata explains how rasa experience pervades the body as fire consumes dry

${ }^{29}$ NS VII offers a framework for emotion-dispositions, and occurrent states, mirrored through emotional contagion by spectators.

${ }^{30}$ tatrāștau bāvāh sthāyinah / trayastrimśadvyabhicārinah / aștau sātvikā iti bhedāh / evamete kāuyarasabhivyaktihetava ekonapañcāśadbhāvāh pratyavagantavyāh / ebhyaśca sāmānyagunayogena rasā nișpadyante // (NS 7.6) 
wood (NS 7.7). ${ }^{31}$ Abhinavagupta further describes the function of vibhāvādi in producing aesthetic enjoyment as different from that of ordinary cause and effect. Rather than viewing art-objects as existing in just one configuration of space and time, aesthetic constructions are seen as real counterparts of cause and effect (causal conditioning), but existing outside the space-time limitations of cause and effect. Thus, the pervasion Bharata speaks of is not a logical pervasion, but rather a spreading of awareness into the embodied spectator.

Ordinarily, a cause of emotion is an embodied response, (cognitive, if involving beliefs) which is about specific objects, persons, etc., and vulnerabilities as such. In contrast, vibhavādi serve the function of stepping away, in a break from the thought of our specific distractions, etc. The quintessential term of art for rasa enjoyment, camatkāra, is the experience of "unobstructed consciousness." This "rest in the self" or pleasure of aesthetic self-contentment is referred to as "repose in the heart" (viśrānti), meaning 'desireless appreciation' (Chakrabarti, 2005). As Navjivan Rastogi explains Abhinavagupta's theory, it is a state of refined consciousness where "The capacity to reflect others and to also identify with the reflected data is distinguishing mark of prakāśa." (2013, 446) ${ }^{32}$ Imaginative causes and effects, vibhāva-s and anubhāva-s remove the obstacles of pragmatic, egotistical, and even intellectual concern through images. (Abh. VI, 1992) ${ }^{33}$ Thus, karuna is a critically reflective precursor to compassion. According to Bharata, the imaginative paths for creating an experience of karuna are: generally seeing in the plot the obstruction (upaghäta) of dharma, a loss of wealth, or the sorrow of a character.

The bhâva-rasa distinction is a split between thinking about particular embodied beings versus the universalized essence of emotions, which are embodied in a spectator's imagination at any time. Rasa-s, real as any other feeing that is telling and so matters, have the added result of sustaining a perspectival shift away from mere relations of particular persons, etc., in their private vulnerabilities. This is where karuna, serves as a guide to moral virtue, but is not a moral virtue of compassion (karuna $\bar{a})$ in itself. The intellectual virtue of karuna is an insightful tendency in the generalization process where dry, rasa-less starting points, such as one's own desires for family and possessions are not the basis of generalization. Inquiring in an as if mode, imaginative possibilities are expressed in śoka, and the matter is of thinking about the larger picture of the relationship between desire, vulnerability, and looming

\footnotetext{
${ }^{31}$ bhavati cātra ślokah-yo'artho hrdayasamvādi tasya bhāvo rasodbhavah / śarīram vyāpyate tena śușkam kāșthabhivāgninā

${ }^{32}$ In "Quintessentiality of Camatkāra in Rasa-Experience" Rastogi identifies prakāśa and vimarśa as being and consciousness. 'A light of consciousness' is one way to understand 'prakāśa' in the idealist, and non-dualist tradition of Śaiva metaphysics and epistemology of Self-recognition. All reality is free playing consciousness, to be reflectively uncovered. Abhinava holds: "The mind of an aesthete is like a clean mirror which allows instant and clear reflection of the content of experience." (Rastogi 2013, 445) ${ }^{33}$ As mentioned earlier, it is not necessarily so much a positive mystical achievement, but rational elimination of seven factors: unfitting narrative, historically spatial-temporal situating of the event, being lost in personal feelings, failure of empathetic imagination, unclarity, general irrelevance, and doubt, to the effect of breaking the barriers of consciousness between one subject and the next (âvarana-bhanga). Also, Chakrabarti 2009, 197
} 
threats to contentment with distance. The aesthetic stance is a creative stance on the part of the spectator, who will then be able to infuse pathos into a judgment. Contrary to assuming judgments that begin with the first-person possessive "my" (sister, husband, child, car, etc. or any personal tragedy therein) the convergence between insight and feeling is critical, and unassuming. Through an unassuming insight, the starting point of a tragic art transcends personal suffering. Since the agent as rasika puts feeling into inquiry that is sublime in itself, and good for being moved, the potential knower critically reflect, and feel freely. The place for moral judgment remains in the world of personal relations, but the place of aesthetic judgment is important for epistemological reasons. Philosophical examples and thought experiments require the shift away from over personalizing, or the discourse will not only lose track of the unfathomable suffering beyond one's trivial concerns, but it will bore the connoisseur, not move inquiry, and leave it dry.

\section{KARUNA-RASA AND THE DISPOSITION OF 'ATTUNEMENT'}

Boldly, we have already argued that a rasa is not a kind of personal emotion, even if a personal emotion inspires the rasa experience. Linda Zagzebski remarks that some emotions (those that are grounded in the ego) are clearly very far removed from intellectual virtues. For this reason, reflection is needed to help to monitor the patterns of fallibility in emotions generally. $(2009,79-80)^{34}$ On Aristotle's view, an aesthetic emotion may be drenched with personal interest (e.g., pity), and less trustworthy. Like cathartic emotions, karunarasa is an emotion the audience feels, and not the feeling of a performer, or character. ${ }^{35}$ In the Poetics, rapture terminates in a recognition (Greek: anagnorisis) of personal relevance-vulnerability to fate, but emotional flooding is directed, the surge of response has a channel and is affectively released. However, as we have argued, egotistical concern is considered to be an obstacle to having a rasa experience. ${ }^{36}$ But as a kind of pleasure, karuna-camatkāra is a wish for continuation of itself as a righteous judgment, which is not the same as a wish for an end to suffering. In catharsis, personal emotions might very well be expunged. If so, then the eliminative function of catharsis actually enhances the positive production of karuna-rasa. But in rasa-camatkāra the essences are savored. Aesthetic tase as tasting is an inward flow. Through the shedding of personal concerns that the spectator is open to see more, able to take in and observe. A distanced and contemplative judgment predominates. Thus, there are internal grounds for thinking that karuna-rasa survives reflection. Aestheticized emotions may regulate dispositions of ordinary emotions, such as pity.

According to K.C. Bhattacharya in "The Concept of Rasa" (1930), we can functionally distinguish emotions as running on three imaginative tracks, primary, sympathetic and contemplative. In a contemplative mode: "Artistic enjoyment is not a

\footnotetext{
${ }^{34}$ (for virtue)

${ }^{35}$ Poetics, Book XI. According to Christopher Gill: "In the Rhetoric Aristotle makes it clear he associates ethos with the presentation, or self-presentation, and pathos with the production of the appropriate reactions in the audience." $(1984,153)$

${ }^{36}$ Abh. VI
} 
feeling of the enjoyer on his own account; it involves a dropping of self-consciousness, while the feeling that is enjoyed - the feeling of the third person-is freed from its reference to an individual subject and eternalised in the Heart Universal." $(2011,186-$ 191) It is perfectly possible to empathize with someone who is feeling love, anger, or disgust on their own terms, without actually feeling those same emotions. Sympathy may be unattached to the desires of the sympathized, fictional or not. The imaginative process of generalization in "moments of taste" constitute a path for judgment to evade one or the other side of the Janus face of 'desire and aversion' linked to private emotions. An audience who perceives universality in the feeling of an artistic presentation, is foremost a sensitive body responsible for what it feels and the trait of inquiring and reimagining the world. Then through imaginative play the agent learns to make use of its freedom to circle around and know desires. The freedom of the sympathetic imagination has an epistemic yield just insofar as the imagination is the vehicle of contemplation leading to deeper understandings.

Kant also noticed that reflective judgment involves an attunement of cognitive faculties. At a critical point in the Critique of Judgment, Kant mentions the attunement between imaginative faculties that is a necessary condition for cognition to take place. (Kant 1987, 163-4) Attunement is not itself an inference or perception. Rather, attunement is a subjective condition for understanding. In the second moment of taste, the universal communicability of a judgment is sensed as an attuned harmony between the faculties of the imagination and understanding. For cognitive beings in reflective judgment, one ought to think other persons could also be receptive to the same harmonizing presentations. From this first level of aligning the faculties of the imagination and understanding in terms of disinterestedness that Kant that provides, a second level of attunement can be built on the aesthetic enjoyment that flows from universal communicability. A possible alignment with the imaginations and understandings of other minds might be available from reflection. In an appreciation of the sublime, ${ }^{37}$ attunement involves seeing deeply (with feeling) existentially derived vulnerabilities that are applicable to all sentient beings. Aestheticized tragedy brings together two senses of attunement for an agent and creates a possibility of inquiring with others that is otherwise difficult to achieve. In a different context, Jessica Benjamin speaks of an in-between space that is created between a therapist and patient with attunement to a depersonalized discourse. Benjamin believes that a basis for attunement may rest in "mirror-neurons":

The third-ness of attuned play resembles musical improvisation, in which both partners follow a structure or pattern that both of them simultaneously create and surrender to, a structure enhanced by our capacity to receive and transmit at the same time in nonverbal interaction. The co-created third has the transitional quality of being both invented and discovered. To the question of "Who created this pattern, you or I?" the paradoxical answer is "Both and neither" (Benjamin 2004 18-19)

\footnotetext{
${ }^{37}$ Kant informally comments that "the feeling for the sublime is stirred" in tragedy $(1764,51)$. Mostly emotions are incongruent with taste on account of personal preferences that sappy emotions express.
} 
Becoming attuned to both faculties, and a narrative, inner discourse appears to be between the listener and the narrator in a manner that accommodates others and is analogous to an immersive form aesthetic appreciation. But insofar as we turn to others to confirm what we ourselves see and feel, attunement is both, of the play of cognitive faculties, and a discursive play between participants. In suddenly appreciating beauty, the expectation that others could also harmonize with art-presentations can elicit a demand. If the distanced nature of the discourse is lost, as may be inevitable, then the thread takes a personal turn, like with an analyst who has lost her bearings:

...the restoration of thirdness in terms of the analyst's recovery of self-observation, such that "we stop doing something that we are probably not aware of doing in our interaction with the patient." I would characterize this... as the analyst's regaining self-regulation and becoming able to move out of dissociation and back into affectively resonant containment. Another way to describe it is that the analyst has to change $(2004,32-33)^{38}$

A self-regulating second-order intellectual virtue of attunement is the capacity tap back into the narrative framework. In karuna-rasa, the rasika reflects according to an attuning schema of observation, and distance. The relation between knower, and possibly known, is sustained by the imagination. In imagining a possibility, one may envision general connections of vulnerability. The rasa-resonance of emotive art is a peculiar kind of knowledge, outside of a single tense, falling into a category of reality which is not applicable only to specific things (Abhinavagupta, 1992, 35-38, Gnoli, 1956). In consciously maintaining a suggested dimension of third-ness, pathos allows deeper insight into apt connections between emotions and vulnerabilities. ${ }^{39}$

This kind of evaluation is described as the state of impersonal subjectivity belonging to a de-centered self where evaluations judge the telling of a sorrow on its own terms. ${ }^{40}$ It is an understanding of subjectivity that does not entail unsharable individual feelings or privacy. (Boruah 2016) ${ }^{41}$ The result for the spectator, according to the classical rasika, Viśvanātha, is that there is no exclusive access to rasa, it is communal. Arindam Chakrabarti $(2009,189)$ translates Viśvanātha's playful description of rasa in the Sāhityadarpana as a reductio of emotional sorts, "another person's, yet not quite another person's, mine, but not just mine" (Viśvanātha 2016, 47). This resembles the schema of third-ness where attunement is possible. Though we do at times picture a rasa as a desire-less emotion because it is distanced, even then, a

\footnotetext{
${ }^{38}$ The "intersubjective view of thirdness" has the structure of sharability in a reflective conceptual analysis.

${ }^{39}$ Pace Benjamin, who is concerned with attunement in a therapeutic context of psychoanalysis, the subject in a decentered state decides on the aptness of second-order desires, neither being swept away, nor invasively observing.

${ }^{40}$ Boruah makes a strong case for aesthetic emotions as a second kind of evaluative judgment in "The impersonal Subjectivity of Aesthetic Emotion", which sets a framework for the normativity of aesthetic emotions as meaningful but objectiveless judgments.

${ }^{41}$ Granted, the intention here is to adhere to a particular construal which strongly emphasizes the nonprivate nature of aesthetic experience along with Viśvanatha on the topic in the Sähityadarpana (The Mirror on Composition)
} 
second-order desire regulates openness to truth and aversion to ignorance. Karunarasa renegotiates resistance, under-distancing, and over-distancing in empathetic engagement. Since rasa does not belong to anyone in particular, karuna is not a private sorrow. But neither is rasa an objective judgment. A 'subject' who experiences rasa is the condition for having rasa. We create, as Benjamin implies with her third-ness, a subject-subject kind of relation. In rasa terms, attunement must rest on a unifity of the subject who engages in contemplation (vimarsia) and the subject who shines forth (prākaśa). ${ }^{42}$ The exact opposite of a didactic tally, karunarasa is an open-ended process of judging the world without determining one's own place in it.

The intellectually sensitive observer recognizes that understanding is subjective. But the check on both ourselves and others is a response to an apt-emotion as it is presented in a narrative. The artwork, poetry and narrative, etc., provides a set of relations for us to respond to and exercise our capacities. Thus, artistic presentations create a kind of a third space that belongs to no one in particular, but is shared by anyone. Not that all arts convey tragic emotion, but karunarasa always conveys a process of universalization where achieving aesthetic enjoyment means that one is receptive to generalizing feelings. This third space is cognitively (and not just pragmatically) significant is because of an expansion of the faculties which occurs in the in-between space of self and others. As K.C. Bhattacharya mentioned, there needs to be an initial track of sentiency as a condition. The Kantian attunement of the faculties starts on the ground level. Some art-objects and narratives seem to make us sense a harmony, and about others we will not feel attuned to the expression, even though it is the faculties that are un-attuned.

\section{CONCLUSION}

As a mean between extremes with a proper motivational component from balancing care for self and others on the level of selflessness, we can hardly interpret karuna $\bar{a}$ the way Aristotle interprets character virtues. The Māhāyāna school's Śāntideva would concede the point, a virtue of compassion is not merely experiencing the pain of another. ${ }^{43}$ An Aristotelian would keep the virtue centered in the self, and concerned with the good it does for the self. Like for Aquinas, other beings are entrenched with the "self" as a means to virtue. Conversely, the bodhisattva is responsible for the liberation of all sentient beings from samsāra in virtue of mutual identification. Great compassion is an outcome of sentiency, and a grasping of the fact that a sentient

\footnotetext{
${ }^{42}$ And from Abhinavagupta's world view, the primordial pair Śiva-Śakti manifested by the soul for the sake of aesthetic enjoyment, or knowledge of Brahmā, references in the Bṛhadāranyaka Upanișad to which Bharata himself was aware of. R.K. Sen. Aesthetic Enjoyment $(1960,17)$

${ }^{43}$ Charles Goodman notes "Central to the spiritual practice of the Theravāda is the cultivation of four qualities known as the Four Divine Abidings (brahma-vihāra); these are lovingkindness (metta), compassion (karuña) , sympathetic joy (pamudita), and equanimity (upekkhā)." $(2009,52)$ In theory, great compassion (mahākarunāa) that embraces all of life transcends ordinary compassion and compassion that is considered impersonal. Though the radically different soteriological doctrines of rasa theorists and Mahāyanna Buddhism are at odds in the debate over the reality of a Self, the narrative of universal suffering that is to be affectively grasped, and grades of emotion to be transcended on levels of selflessness, entails that the generalization of suffering is at stake for epistemic reasons.
} 
response can be de-centered. In the ontological identification between the self and others, and the emptiness of both, suffering supposedly becomes ownerless, and hence, any pain is both massive, and in some sense trivial. Against this kind of a no-self view, Abhinavagupta maintains a stance that makes a transition away from selfishness possible, but only on the condition that the nature of aesthetizization is a self. In the rasa experience, which is a free play, there is a breaking of conceptual distinctions constituting individual selves. From a vantage point of karunarasa, an array of ordinary emotions that Nussbaum describes are necessarily connected:

If we now consider in a more general way the passage from one emotion to another, we find that we now have a deeper understanding of why the emotions should be grouped together as a class. It is not only that fear, grief, anger, love, and the others all share certain features...It is that they have a dynamic relation to one another $(2002,97)$.

The causal links are invisible, and they tear people apart into their own private suffering. Observing selfish sorrow, and the icy distance between harmer and harmed, the relations between self and other shine forth. To aestheticize emotions is to take the evaluative response out its ordinary context, to be moved by observing the subject, of say Ophelia, as she plays out. Beliefs are not an important part of the cognitive value of rasa, but choosing how to judge beliefs and desires is part of aesthetic experience. Inquiry can change beliefs, desires and emotion.

The methodology of the rasa theorists who suppose that aesthetic enjoyment is real, and that our theory of emotions fit with what is presented on stage, Bharata and Abhinavagupta, make enactment test of aptness for karuna. Without presupposing the truth of any view, Buddhist or otherwise, Abhinavagupta often takes many conflicting views and finds insights that each one has to offer. He accepts points from his idealist Buddhist opponents, and he uses examples of Buddhist literature in discussing the rasa most linked to soteriological aims, śānta (in the Abhinavabhāratī). His insight there is that discourse and aesthetic enjoyment transcends tenets. Ordinary compassion might be a 'way of knowing' other minds. However, karuna has a different structure and suggests a different intervention in inquiry. Self-understanding is by a sentient agent constituted by emotions, and is more accessible in an aesthetic context because as tragedy becomes truly unselfish, the rasika--a freely judging agent--steps out of the personal-impersonal dichotomy into an epistemic domain in which the emotion belongs to everyone and no one in particular who share in a capacity of sentience. Augmented by reflection, relishable-sorrow moves the questioner who may transform karuna imaginings into genuine wisdom.

The emotion-disposition of 'attunement' adds to inquiry an alignment with the imaginations and understandings of others in order to create a holistic picture of knowers. The attuned spectator observes, and notices more than with reliabilist virtues. As pathos, or a reflective emotion, karuna can be regulative of intellectual virtues. Selfish sorrow leading to biased understanding is challenged in the aesthetic transformation of tragedy. As a reflective judgment, karuna is a refuge from even others' vulnerabilities. Aestheticizing tragedy complements inquiry because not only 
does appreciation involve inherently pleasurable emotions when ordinary counterparts are painful and cause the agent to retreat from a discourse, the aesthetic context also involves an evaluation of pleasure separate from personal preferences. Because we are able to know feelings free from desire in judging a tragic circumstance, the aptness of feeling karunarasa raises other critical questions, including the second order question: how ought one feel? We can now mark that karunarasa is epistemically relevant in a new way.

\section{ACKNOWLEDGEMENTS}

There are several insightful scholars to whom I am grateful for fostering a sustained discourse around intellectual virtue and karuna. Foremost, I wish to thank the two anonymous referees of the journal Comparative Philosophy for generously offering their time and for their critical work in providing substantial feedback. Their disinterested interest in preserving philosophical distinctions was invaluable in this project to clarify the philosophical positions surrounding aesthetic emotions in a comparative context. I also wish to thank Vrinda Dalmiya for her encouragement and critical engagement, Jesse Knutson for readings together with the delight of a true raskia, Arindam Chakrabarti for questioning at every stage, and Rajam Raghunathan for inspiring inquiry into the relation between wisdom and compassion. Thanks to Prem Raina for a torrent of thoughts on churning watery narratives of tragedy into rasa.

\section{REFERENCES}

Aristotle (1984), The Complete Works of Aristotle: The Revised Oxford Translation. Vol. 2. trans. Jonathan Barnes, (Princeton University Press): 2316-40.

Ānandavardhana, and Abhinavagupta Dhvanyālokalocana trans. Daniel Ingalls, (1990), The Dhvanyāloka of Anandavardhana with the Locana of Abhinavagupta. (Cambridge, MA: Harvard University Press).

Ashton, Geoff and Tanner, Sonja (2016), "From Puzzling Pleasures to Moral Practices: Aristotle and Abhinavagupta on the Aesthetics and Ethics of Tragedy", Philosophy East \& West 66.1: 13-39. < doi:10.1353/pew.2016.0008.>

Bharatamuni, and Abhinavagupta Nātyaśāstram. Trans. K. Krishnamoorthy. (1992) The Nātyaśāstra of Bharata, with the Abhinavabhāratī of Abhinavagupta, Vol. 1, 4th ed. (Baroda: Oriental Institute).

Bhattacharya, K. C. (2011), "The Concept of Rasa (1930).", Indian Philosophy in English from Renaissance to Independence, edited by Nalini Bhushan and Jay L. Garfield (Oxford: Oxford Univeristy Press), 195-206.

Benjamin, Jessica (2004), "Beyond doer and done to/ An intersubjective view of thirdness" Psychoanalytic Quarterly Volume 72.1, 5-46 <https://doi.org/10.1002/ j.2167-4086.2004.tb00151.x> 
Bhavabhūti Uttararāmacarita trans. M. R. Kale (2006), (Delhi: Motilal Banarsidass Publishers).

Boruah, Bijoy (2016), "The impersonal Subjectivity of Aesthetic Emotion" in Arindam Chakrabarti (ed.), Bloomsbury Research Handbook of Indian Aesthetics (London: Bloomsbury), 127-148.

Boruah, Bijoy (2002), Fiction and Emotion: A study in aesthetics and the philosophy of mind. (Oxford: Clarendon Press).

Chakrabarti, Arindam (2016), "Introduction: contemporary Indian aesthetics and philosophy of art" in Arindam Chakrabarti (ed.), The Bloomsbury research handbook of Indian aesthetics and the philosophy of art (London: Bloomsbury Academic), 1-24.

Chakrabarti, Arindam (2015), “How Do We Read Others' Feelings? Strawson and Zhuangzi Speak to Dharmakirti, Ratnakīrti, and Abhinavagupta" in Arindam Chakrabarti and Ralph Werber (eds.), Comparative Philosophy Without Borders (London: Bloomsbury Academic), 95-117.

Chakrabarti, Arindam (2009), "Play, Pleasure, Pain: Ownerless Emotions in RasaAesthetics" in D.P. Chattopadhyaya and Amiya Dev (eds.) History of Science, Philosophy, and Culture in Indian Civilization. 40.3:14 (New Delhi: Center for Study in Civilizations). 189-202.

Chakrabarti, Arindam (2005), "Heart of Repose, The Repose of the Heart: A Phenomenological Analysis of the Concept of Viśrānti" in Sadananda Das and Ernst Fürlinger (eds.), Samarasya: Studies in Indian Arts, Philosophy, and Interreligious Dialogue: in Honour of Bettina Bäumer. (New Delhi: D.K. Printworld), 27-36.

Coplan, Amy (2011), "Understanding Empathy: Its Features and Effects" in Amy Coplan and Peter Goldie (eds.), Empathy Philosophical and Psychological Perspectives (New York: Oxford University Press), 3-18.

Dalmiya, Vrinda (2016), Caring to Know: Comparative Care Ethics, Feminist Epistemology, and the Mahābhārata. (New Delhi: Oxford University Press).

Dalmiya, Vrinda (2001) "Knowing People" in Matthias Steup (ed.) Knowledge, Truth, and Duty: Essays on Epistemic Justification, Responsibility, and Virtue, (New York: Oxford University Press), 221-33. <https://doi.org/10.1093/0195128923 $.003 .0014>$

Ekman, Paul (1999) "Basic Emotions" in Tim Dalgleish and Mick J. Power (eds.) Handbook of Cognition and Emotion (John Wiley \& Sons, Ltd) 45-60

Gill, Christopher (1984), "The Ëthos/Pathos Distinction in Rhetorical and Literary Criticism”, The Classical Quarterly, (Cambridge: Cambridge University Press). Vol. 34:1, 149-166.

Gnoli, Raniero (1956), The aesthetic experience according to Abhinavagupta (Roma: Is. M.E.O.).

Gallese, Vittorio (2017), "The Empathic Body in Experimental Aesthetics - Embodied Simulation and Art" in V. Lux, and S. Weigel (eds.), Empathy, Palgrave Studies in the Theory and History of Psychology, 181-199. <https://doi.org/10.1057/978-1137-51299-4_7> 
Gallagher, Shaun, and Zahavi, Dan (2008), Phenomenological Mind. An Introduction to Philosophy of Mind and Cognitive Science. (New York: Routeledge)

Goodman, Charles (2009), Consequences of Compassion An Interpretation and Defense of Buddhist Ethics. (New York, Oxford University Press).

Hookway, Christopher. (2003), "How to be a Virtue Epistemologist" Intellectual Virtue: Perspectives from Ethics and Epistemology. Linda Zagzebski ed. (Oxford: Clarendon Press).

Housset, Emmanuel. "The Paradoxes of Pity" in Care, Compassion and Recognition. Carlo Leget, Chris Gastmans and Marian Verkerk, (eds.) (Leuven: Peeters), 71-87.

Kant, Immanuel (1790), Kritik der Urteilskraft. trans. Werner S. Pluhar (1987), Critique of Judgment (Indianapolis: Hackett).

Kant, Immanuel (1764) Beobachtungen über das Gefühl des Schönen und Erhabenen John Goldthwait, trans. (1960), Observations on the Feeling of the Beautiful and the Sublime. (Los Angeles: University of California Press).

Kushwaha, Mahesh Singh, ed. (1988). Indian poetics and Western thought. (Lucknow: Argo Press).

Langton, Rae (2018), "Empathy and First-Personal Imagining" Proceedings of the Aristotelian Society, Volume 119, Issue 1, April 2019, 77104. <https://doi.org/10.1093/arisoc/aoz006>

Masson, J. L., and M. V. Patwardhan (1985), Śāntarasa: Abhinavagupta's Philosophy of Aesthetics (Poona: Bhandarkar Oriental Research Institute).

Nussbaum, Martha C (2008), Upheavals of thought: the intelligence of emotions. (Cambridge: Cambridge University Press)

Prinz, Jesse (2004), “Which Emotions Are Basic?” in Dylan Evans and Pierre Cruse (eds.) Emotion, Evolution, and Rationality, (New York: Oxford University Press).

Rastogi, Navjivan (2013), "Quintessentiality of Camatkāra in Rasa-Expereince in Perspectives on Abhinavagupta: Studies in Memory of K.C. Pandey on His Centenary. (New Delhi: Munshiram Manoharlal Publishers), 429-455.

Ratié, Isabelle (2009), "Remarks on Compassion and Altruism in the Pratyabhijñā Philosophy" Journal of Indian Philosophy 37:349-366 $<\underline{\text { https://doi.org/10.1007/s10781-009-9066-z }>}$

Singal, R. L. (1977), Aristotle and Bharata: A Comparative Study. (Punjab: Vishveshvaranand Vedic Research Institute).

Sorabji, Richard (2000), Emotion and Peace of Mind: From Stoic Agitation to Christian Temptation: The Gifford Lectures. (New York: Oxford University Press).

Stamatopoulou, Despina (2017), "Empathy and the aesthetic: Why does art still move us?" Cogn Process 19, 169-186. < https://doi.org/10.1007/s10339-017-0836-3>

Śāntideva Bodhicaryāvatāram trans. Kate Crosby and Andrew Skilton (1995), The Bodhicaryāvatāra. (New York: Oxford University Press).

Vālmīki Rāmāyaṇam. trans. Robert P. Goldman (2005), The Rāmāyaṇa: Book One Boyhood. (New York: New York University Press).

Viśvanātha. Sāhityadarpaṇaḥ. trans. J.R. Ballantine and Pramadā Dasā Mitra (1965), Mirror on Composition (Delhi: Motīlāl Banārasīdās). 
Woodruff, Paul (2016), "Sharing Emotions Through Theater: The Greek Way" Philosophy East and West, Vol 66, Number 1, January 2016, 146-151. $<$ DOI: $10.1353 /$ pew.2016.0010>

Woodruff, Paul (2013), "Spectator Emotions" in John Deigh (ed.) On Emotions: Philosophical Essays. (New York: Oxford University Press), 59-75.

Zagzebski, Linda Trinkaus (1996), Virtues of the mind: an inquiry into the nature of virtue and the ethical foundations of knowledge. (Cambridge: Cambridge University Press).

Zagzebski, Linda Trinkaus (2009), On Epistemology, (Belmont, CA: Wadsworth, Cengage Learning)

Zahavi, Dan (2008), "Simulation, projection and empathy" in Consciousness and Cognition 17(2):514-522 <DOI: 10.1016/j.concog.2008.03.010> 